\title{
Design of Assistance to Reduce WorkRisk in the Packing Process of Liquid Detergent Authors: Popy Yuliarty ${ }^{1}$; Faisol Ardhi $\mathbf{H}^{2}$; Rini Anggraini ${ }^{3}$; Atiek Ike Wijayanti ${ }^{4}$
}

\author{
Department of Industrian Engineering Universitas Mercu Buana, \\ Jakarta $11650^{12}$ Department of Mechanical Engineering Universitas \\ Mercu Buana, Jakarta $11650^{3}$ \\ Department of Industrian Engineering Sekolah Tinggi Teknologi Bina Tunggal, Bekasi \\ $17134^{4}$ \\ Corresponding author : popy.yuliarty@mercubuana.ac.id ${ }^{1}$ : \\ rini_anggraini@mercubuana.ac.id ${ }^{3}$ \\ 10.26821/IJSHRE.9.7.2021.9512
}

\begin{abstract}
Abstract: This research was conducted in a business that is engaged in the chemical industry which produces various kinds of chemical products, such as: detergents, dish soap, floor cleaners, softeners, and others. To carry out the production process, this company still uses the semi- manual method, which means that most of the production activities still use human labor. The problem was found in the finished product packaging section, namely the work position of the packaging department employees who caused complaints of back pain. The problems that occur in this study are how to determine the level of risk to the packaging department employees with their current work position and how to make a packaging process tool design. The results obtained based on REBA calculations are included in the moderate category (actiob level 2, REBA score 4-7) which means that it requires corrective action. The design of aids in the detergent packaging process is made based on the anthropometry of the body of the employees by considering the anthropometry of the body ofIndonesians in general.
\end{abstract}

Keywords: packaging, tools,fatique, NBM,REBA

\section{Introduction}

Ergonomics is the study of human relations and the workplace. One of the studies in it is anthropometry. With human anthropometric data, it can make it easier to design a good, comfortable and safe workplace (Anisah, Yuliarty \& Anggraini, 2018). Ergonomics is a systematic branch of science to utilize information about the nature, abilities and limitations of humans in designing a work system, so that people can live and also work in a good system, namely to achieve the desired goals through effective, efficient, safe work. and comfortable (Rosnani, 2010).

The design of the workplace will depend on the type of work and the tools or facilities used to support the implementation of work operations. One of the efforts made to produce quality products is to pay attention to hazards and risks including environment, health and safety.

Popy Yuliarty; Faisol Ardhi H ;Rini Anggraini; Atiek Ike Wijayanti, Volume 9 Issue 7, pp 53-59 July 2021 
The application of ergonomics needs to get sufficient attention because of the lack of attention to the application of ergonomics in the workplace so that the risk of existing hazards can be reduced (Dzikrillah \& Yuliani, 2017). Likewise with the importance of a good work position, where every activity or job that is carried out if it is not ergonomic will result in inconvenience, accidents, disease, high costs, decreased performance which will result in a decrease in work efficiency. Therefore, it is necessary to improve a good and ergonomic work position in order to increase productivity. This research was conducted at a business that is engaged in the chemical industry located in South Tangerang. This company produces various kinds of chemical products, such as: detergents, dish soap, floor cleaners, softeners, and others. These products are then distributed or sold to Loundry, hotels / inns, restaurants, and households. To carry out the production process, this company still uses the semi-manual method, which means that most of the production activities still use human labor.

In this research, we will focus on activities that produce detergents because according to information from this business owner, this product is the best-selling product and is often produced compared to other products. The production capacity of the liquid detergent production process can produce approximately 1,000 liters. Then the liquid detergent production results are packed into 5 liter packages. The average length of time for packing per 5 liters is $40 \mathrm{~s} / 5$ liters while the production is 1,000 liters, therefore it takes about 2.22 hours to complete the packing process. With such time to carry out the packing process, complaints from packing workers arise such as fatigue, back pain, waist, right arm, and neck. The results of observations made at work sites found that work attitudes that cause employee fatigue and discomfort are caused by an unergonomic work position.

With the current working position, if a solution is not found, it will have a negative impact on the packing

department employees, namely the emergence of complaints of back pain. Based on this, the researcher will try to solve the problem to improve the work position by designing a tool in an effort to solve the problem that occurs.

NBM questionnaires were distributed to identify the level of discomfort of workers. The Nordic Body Map questionnaire is the questionnaire most often used to determine workers' discomfort, and this questionnaire is most often used because it is standardized and neatly arranged according to Kroemer (1994) in Widodo (2015). According to Sukania (2016), through the Nordic Body Map approach, it can be seen which parts of the muscles are experiencing complaints with the level of complaints ranging from discomfort (a little pain) to very pain. The REBA method in ergonomics is used to rapidly assess the posture of a worker's neck, back, arms, wrists and feet. REBA more generally, in the addition of one of the new systems in the analysis which includes dynamic and static factors of the individual loading interaction form of loading, and a new concept related to consideration with the title "The Gravity Attended" to prioritize the position ofthe most superior. (Ocean, 2018)

\section{Research Methodology}

1. NBM questionnaires were distributed to identify the level of discomfort of workers. The Nordic Body Map questionnaire is the 
questionnaire most often used to determine workers' discomfort, and this questionnaire is most often used because it is standardized and neatly arranged according to Kroemer (1994) in Widodo (2015). According to Sukania (2016), through the Nordic Body Map approach, it can be seen which parts of the muscles are experiencing complaints with the level of complaints ranging from discomfort (a little pain) to very pain.

2. The REBA method in ergonomics is used to rapidly assess the posture of a worker's neck, back, arms, wrists and feet. REBA more generally, in the addition of one of the new systems in the analysis which includes dynamic and static factors of the individual loading interaction form of loading, and a new concept related to consideration with the title "The Gravity Attended" to prioritize the position of the most superior. (Ocean, 2018).

3. AutoCAD is a program that is commonly used for specific purposes in drawing and designing with the help of computers in the formation of two- and three- dimensional or more dimensions known as "Computer- aided drafting and design program" (CAD).The drawing program system that can help this computer will provide convenience in generating the right model to meet special needs in addition to all information in the size that can be used in the form of reports, Material Assessment (BOM), simple functions and numerical form and so on. With the help of this system it can produce work at the skill stage and a high degree of accuracy in addition to saving time by only needing to give a few instructions and easy ways .

\section{Data Collection and Processing}

\section{Data Collection}

The data collected can be described as follows:
Initial data collected by researchers based on current workpositions can be seen in Figure 1.

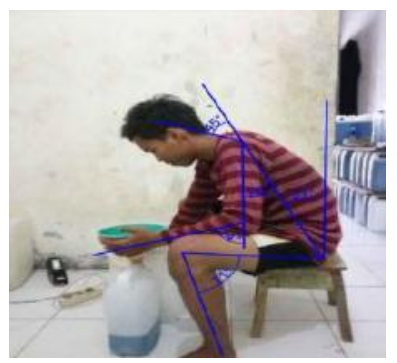

Figure 1. Packaging employee work position The NBM questionnaire was given to employees to find out the complaints experienced by employees during the packaging process. The results of the NBM questionnaire recap

\section{Data Processing}

The calculation of the Rapid Entire Body Assessment (REBA) is carried out to determine the level of risk that occurs in employee complaints. Table 2. below is the result of REBA calculation:

Table 2. Result of REBA

\begin{tabular}{|l|l|l|}
\hline & Movement & Final \\
Neck & $>20^{0}$ flexion & 3 \\
\hline Truck & $20^{0-} 60^{0}$ flexion & 3 \\
\hline Legs & sit & 1 \\
\hline Table A score & & 5 \\
\hline Weight score & $5 \mathrm{~kg}-10 \mathrm{~kg}$ & 2 \\
\hline Table A final scores & & 7 \\
\hline Upper arm & $20^{0-} 45^{0}$ flexion & 3 \\
\hline Lower arm & $60^{0-} 100^{0}$ flexion & 1 \\
\hline Wrist & $0^{0-} 15^{0}$ & 2 \\
\hline Table B scores & & 4 \\
\hline Table B Final Scores & & 4 \\
\hline Table C scores & & 5 \\
\hline Activities scores & & 2 \\
\hline REBA final scores & & 7 \\
\hline
\end{tabular}

With the final score of 7 it can be said that the 
Volume 9 Issue 7 July 2021

job has a "medium" level of risk, and requires action as can be seenin table 3. Following :

Table 3. Level of Risk REBA

\begin{tabular}{|c|c|c|c|}
\hline $\begin{array}{c}\text { Action } \\
\text { Level }\end{array}$ & $\begin{array}{c}\text { REBA } \\
\text { Scores }\end{array}$ & $\begin{array}{c}\text { Risk } \\
\text { Level }\end{array}$ & Action \\
\hline 0 & 1 & $\begin{array}{c}\text { Can be } \\
\text { ignored }\end{array}$ & Not need \\
\hline 1 & $2-3$ & Low & May need \\
\hline 2 & $4-7$ & Medium & Need \\
\hline 3 & $8-10$ & Hight & $\begin{array}{c}\text { As soon as } \\
\text { possible }\end{array}$ \\
\hline 4 & $11+$ & $\begin{array}{c}\text { Very } \\
\text { Hight }\end{array}$ & $\begin{array}{c}\text { Need right } \\
\text { now }\end{array}$ \\
\hline
\end{tabular}

Since there are only 2 employees, we go straight to calculating the mean and standard deviation. The results of calculating the mean and standard deviation of employee anthropometric measurements can be seen intable 4 below:

Table 4. Mean and standart deviation employee anthropometric

\begin{tabular}{|l|c|c|}
\hline \multicolumn{1}{|c|}{ Elements } & $\begin{array}{c}\text { Mean } \\
(\mathrm{cm})\end{array}$ & $\begin{array}{c}\text { Standart } \\
\text { deviation } \\
(\mathrm{cm})\end{array}$ \\
\hline $\begin{array}{l}\text { D8 : elbow heigh sitting } \\
\text { possition }\end{array}$ & 24,2 & 0,14 \\
\hline D14 : popliteal length & 38,5 & 0,42 \\
\hline D15 : knee heigth & 52,05 & 0,92 \\
\hline D16 : popliteal heigth & 41,25 & 0,21 \\
\hline D19: hip width & 31,7 & 0,14 \\
\hline D22: upper arm length & 34.65 & 0,07 \\
\hline D23: lower arm length & 46 & 0,42 \\
\hline D32: length of the hand & 172,92 & 0,92 \\
\hline
\end{tabular}

The design of the dimensions of the frame is calculated using anthropometry of the limbs in a sitting position. The following data on the measurement results of employee anthropometric dimensions can be seen in table 5 the following:

Table 5. Employee anthropometric

\begin{tabular}{|c|c|c|}
\hline $\begin{array}{c}\text { Number of } \\
\text { elemt }\end{array}$ & $\begin{array}{c}\text { Employee } \\
1\end{array}$ & $\begin{array}{c}\text { Employee } \\
2\end{array}$ \\
\hline D11 & 24,5 & 24,3 \\
\hline D14 & 38,8 & 38,2 \\
\hline D15 & 52,7 & 51,4 \\
\hline D16 & 42 & 41,7 \\
\hline D19 & 31,8 & 31,6 \\
\hline D22 & 34,7 & 34,6 \\
\hline D23 & 46,3 & 45,7 \\
\hline D32 & 173,4 & 172,1 \\
\hline D36 & 69,8 & 68,3 \\
\hline
\end{tabular}

centile calculation is a value that indicates a certain percentage of people who have a measure at or below that value. In this calculation, the 5th percentile is used for all anthropometric data which can be seen in Table 6 below:

Table 6. Percentile calculation

\begin{tabular}{|l|c|}
\hline \multicolumn{1}{|c|}{ Elements } & Percentile \\
\hline D8 : elbow heigh sitting possition & 24,21 \\
\hline D14 : popliteal length & 37,81 \\
\hline D15 : knee heigth & 50,54 \\
\hline D16 : popliteal heigth & 41,50 \\
\hline D19: hip width & 34.70 \\
\hline D22: upper arm length & 34,53 \\
\hline D23: lower arm length & 45,31 \\
\hline D32: length of the hand & 171,24 \\
\hline D36: long handle arm forward & 67,31 \\
\hline
\end{tabular}


Volume 9 Issue 7 July 2021

Next is to calculate the dimensions of the tool.

Dimensional calculations are carried out to determine the design of the tool to be made. The calculation of this dimension refers to the results of the percentile calculationthat has been done previously. In determining the dimensions of the design tools, the 5 th percentile is used, the 5 th percentile is used to determine the width, height, and length of the packing aid design. This is so that individuals who have minimum body

dimensions do not feel great when using these tools, and individuals who have maximum body dimensions do not feel too small. Sothat the design of tools can be comfortably used by each individual. The tools here are working tables and chairs for packaging. The design of this packaging aid design can be seen in Figure 1 below:
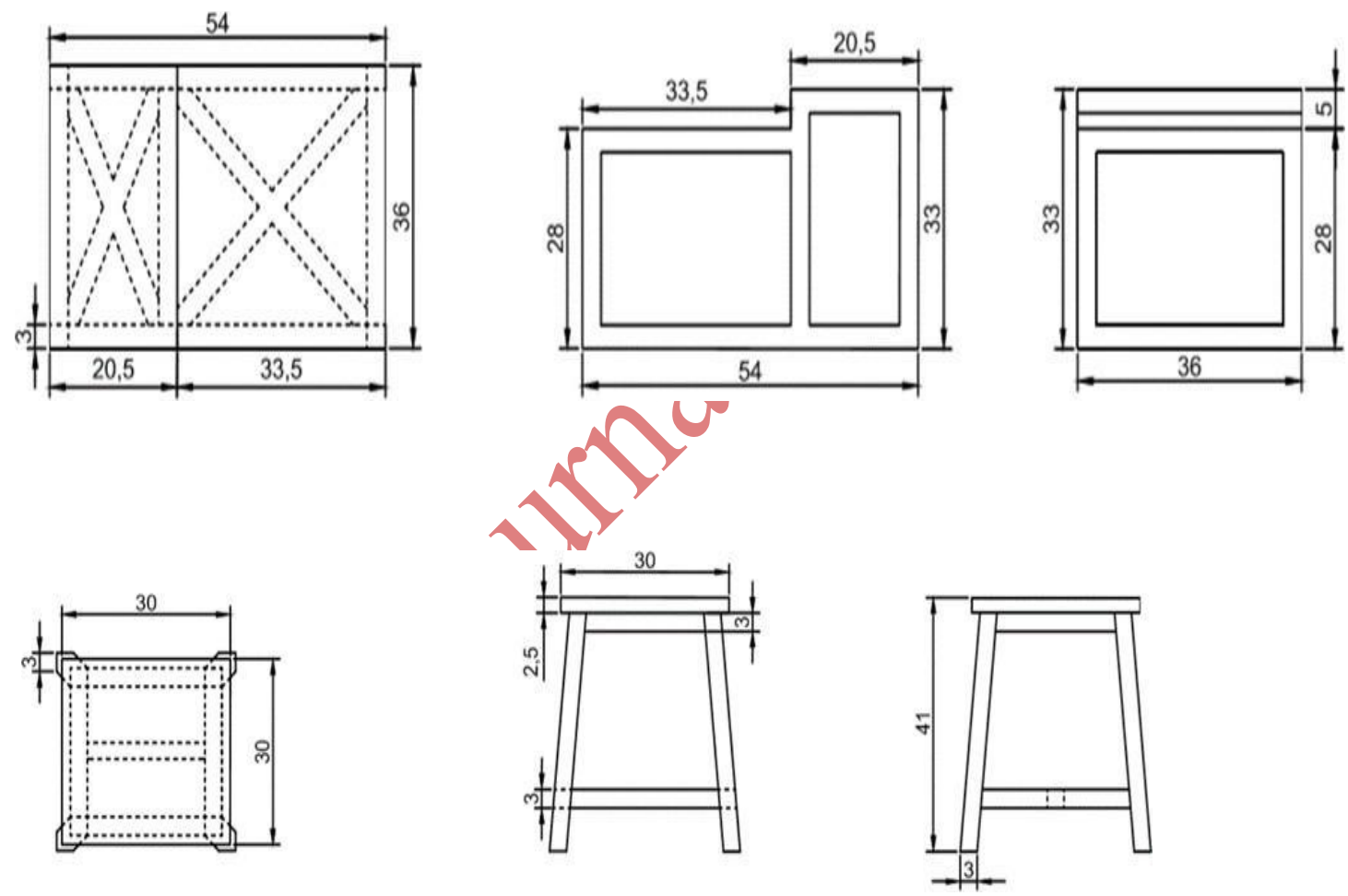

Figure 1. Packaging tools design

After getting the specifications as well as the design design from the research results, then the next step is the design of packing tools aimed at improving employee work posture.
The design of packaging tools with Auto CAD can be seenin Figure 2 below: 
Volume 9 Issue 7 July 2021

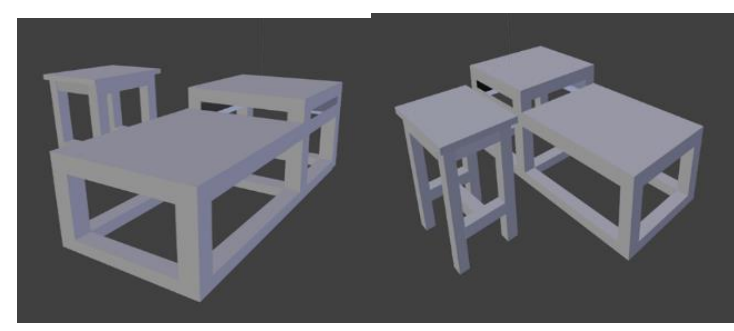

Figure 2. Packaging tools design.

The design of packaging aids is carried out to change the attitude or work posture of employees. This change was made based on complaints and consideration of interview results as well as distributing questionnaires given to workers. The design is carried out with an anthropometric approach according to ergonomic principles, so that it is expected to minimize the complaints that are felt.

\section{Conclusion}

The conclusions that can be drawn in this study are:

1. The level of work risk for employees in the detergent packaging process based on the Nordic body map (NBM) questionnaire and the rapid entire body assessment (REBA) is a "medium" risk level with a score of " $4-7$ ", and requires an improvement.

2. The design of aids in the detergent packaging process is based on the anthropometry of the body of the employees by taking into account the anthropometry of the body of Indonesians in general.

3. Research on occupational health and safety needs to be carried out in all current production to avoid fatigue and work-related accidents because they will have bad consequences for the company and the employees themselves.

\section{Acknowledgments}

The authors give special appreciation to Universitas Mercu Buana Jakarta, Sekolah Tinggi Teknologi Bina Tunggal and for research funding.

\section{Refferences}

Alatas, A. H., \& Putri, R. J. K. (2017). Identifikasi Human Error pada Proses Produksi Cassava Chips dengan Menggunakan Metode SHERPA dan HEART di PT. Indofood Fritolay Makmur. Jurnal PASTI.

Anisah, Yuliarty, P., \& Anggraini, R. (2018). Perancangan Tempat Wudhu Ergonomis Berdasarkan Antropometri Pengguna . ( Studi Kasus Pada Mall $A b c \quad, . \quad X I I$

$284-290$.

https://publikasi.mercubuana.ac.id/i ndex.php/pasti/a rticle/view/4982

Dzikrillah, N., \& Yuliani, E. N. S. (2017). Analisis Postur Kerja Menggunakan Metode Rapid Upper Limb Assessment (Rula) Studi Kasus Pt $\mathrm{Tj}$ Forge Indonesia. Jurnal Ilmiah Teknik Industri.

https://doi.org/10.24912/jitiuntar.v3i3. 466

Fitri, A.D., Irfani, T.H., \& Bahar, E. 2018. Association of Ergonomic Risks with Work Musculoskeletal Disorders Complaints Among Sate and Gadogado Peddlers in Palembang. Journal of International Pharmaceutical Research Volume 45

Garkaz, A., Kurd, N., Moatamedzade, M., \& Shirmohamadi, N. 2014. Ergonomic 
Volume 9 Issue 7 July 2021

assessment of Sina car montage industry employees 'working positions by REBA (Rapid entire body assessment). J Bas Res Med Sci 2014; 1(3):52-59

Ingale, P.A., \& Salunke, P.V. 2016. Rapid Entire Body and Rapid Upper Limb Assessment of Operator for Multipurpose Wheel Lathe Machine. IJMEIT// Vol.04 Issue 03//March//Page No:1636-1641//ISSN-2348$196 x$

Karuniastuti, N. (2013). Bahaya Plastik terhadap Kesehatan dan Lingkungan. Swara Patra: Majalah Pusdiklat Migas.

Middlesworth, M. (2014). A Step-by-Step Guide Rapid Entire Body Assessment ( REBA ). Ergonomics Plus Inc. https://doi.org/10.1016/S0003-6870(99)00039-3

Nadri, H., Fasih, F., Nadri, F., \& Nadri, A.2015. Comparison of ergonomic risk assessment results from Quick Exposure Check and Rapid Entire Body Assessment in an anodizing industry of Tehran, Iran. JOHE, Autumn 2013; 2(4)

Rahman, A. 2013. Antropometri Indonesia (The largest anthropometry data in Indonesia). Diakses pada https://antropometriindonesia.org/index.ph p

Rosnani, G. (2010). Perancangan Produk. In Graha Ilmu. Samudra, P. A. (2018). Analisis Keamanan Aktivitas

Penyablonan pada Morfo Industries dengan Menggunakan Metode RULA dan REBA. JurnalPASTI.

Setyaningsih, L., Anna, B., \& Purbasari, A. 2016. Perancangan footrest untuk mengurangi kelelahan operator pada bagian kaki di cell s/a coil xs156 di pt.abc. Jurnal PASTI Volume X No. 2, $126-137$
Sukania, I. W., Ariyanti, S., \& Adhitian, A. (2016). PERANCANGAN ROTARY TABLE SEBAGAI FASILITAS PADA STASIUN KERJA WATERBASE PT. TRIPLAST INDONESIA.SINERGI.

https://doi.org/10.22441/sinergi.2016.1.0

08 Tanjung, S. (2015). Analisis Postur Kerja Menggunakan

Metode Rula untuk Mengurangi Risiko Musculoskeletal Disorders (Studi Kasus pada Pekerja di Plant Kt-24, PT Bakrie

Pipe Industries). Jurnal Ilmiah Universitas Bakrie.

Torik. 2016. Analisa postur pengendara motor untuk evaluasi dimensi bagian tempat dudukan. SINERGI Volume XX No. 3, $223-228$

Yuliani, E.N.S. 2009. Pengukuran pengeluaran energi dan penilaian beban kerja fisik N karyawan perguruan tinggi X. Jurnal PASTI Volume V No. 3, 2085- 5869

Wignjosoebroto. (2012). Ergonomi, studi gerak dan waktu: teknik analisis untuk peningkatan produktivitas kerja. In University of Sumatera Utara Library. https://doi.org/10.1002/cmr.a.20146 